\title{
PEMBELAJARAN PUISI JAWA DI SMP NEGERI 3 SUKOHARJO
}

\author{
Sri Harjono Basuki \\ Prodi Pendidikan Bahasa dan Sastra Daerah, FKIP, \\ Univeristas Veteran Bangun Nusantara Sukoharjo \\ E-mail: Sri_harjono70@yahoo.com
}

\begin{abstract}
Abstrak
Tujuan penelitian ini ada dua (1) Untuk mendeskripsikan karakteristik pengelolaan pembelajaran apresiasi puisi jawa di SMP Negeri 3 Sukoharjo. (2) Untuk mendeskripsikan karakteristik interaksi pembelajaran apresiasi puisi jawa di SMP Negeri 3 Sukoharjo. Jenis penelitian ini adalah penelitian kualitatif. Penelitian dilakukan di SMP Negeri 3 Sukoharjo. Teknik pengumpulan data menggunakan wawancara mendalam dan dokumentasi. Teknik analisis data dengan tiga komponen utama yaitu reduksi data, sajian data, dan penarikan simpulan serta verifikasinya. Hasil penelitian ini adalah (1) Pengelolaan pembelajaran apresiasi geguritan di SMP Negeri 3 Sukoharjo dilakukan dalam tiga tahap, yaitu tahap perencanaan, pelaksanaan, dan evaluasi pembelajaran. Perencanaan pembelajaran apresiasi Geguritan disusun oleh guru bahasa Jawa berdasarkan rencana atau RPP yang telah dibuat menurut jadwal semester atau alokasi waktu yang ada. Pelaksanaan pembelajaran dilakukan dalam tiga tahap pembelajaran yaitu kegiatan pendahuluan, kegiatan inti dan kegiatan penutup. Kegiatan inti guru melakukan kegiatan elaborasi eksplorasi dan konfirmasi dalam pembelajaran apresiasi Geguritan, dengan metode unjuk kerja, ceramah, demonstrasi, penugasan kelompok dan tanya jawab. Sedangkan evaluasi berbentuk uji petik kerja atau bisa juga test tertulis. (2) Interaksi antara guru dan peserta didik terjalin dengan baik dan akrab baik itu sebelum pembelajaran maupun pada saat pembelajaran di kelas, yang ditandai dengan keaktifan siswa dalam mengikuti pembelajaran sampai akhir kegiatan proses belajar mengajar dengan memanfaatkan secara maksimal fasilitas yang diberikan oleh guru. Bentuk interaksi antara guru dan peserta didik terjadi secara dua arah sehingga menimbulkan timbal balik yang baik antara guru dan peserta didik.
\end{abstract}

Kata-kata kunci: pengelolaan pembelajaran, interaksi pembelajaran, geguritan.

\section{JAVANESE POETRY LEARNING IN SMP NEGERI 3 OF SUKOHARJO}

\author{
Sri Harjono Basuki \\ Regional Language and Literature Education, FKIP, \\ Veteran Bangun Nusantara University of Sukoharjo \\ E-mail: Sri_harjono70@yahoo.com
}

\begin{abstract}
The research has two purpose (1) To describe the characteristics of learning management Javanese poetry appreciation in SMP Negeri 3 Sukoharjo. (2) To describe the characteristics of the learning interaction Javanese poetry appreciation in SMP Negeri 3 Sukoharjo. This research is qualitative research. The study was conducted at SMP Negeri 3 Sukoharjo. Data collection techniques using indepth interviews and documentation. Data analysis techniques with three main components, namely data reduction, data presentation, and drawing conclusions and verification. The results of this study were (1) appreciation of learning management geguritan in SMP Negeri 3 Sukoharjo conducted in three phases, namely the planning, implementation, and evaluation of learning. Learning plan developed by a teacher appreciation Geguritan Java language based plans or lesson plans that have been made ahead of the semester or the allocation of time. Implementation of the learning is done in three phases, namely a preliminary study, the core activities and the closing. Core activities teachers undertake exploration
\end{abstract}


activities elaboration and confirmation in learning Geguritan appreciation, by the method of performance, lectures, demonstrations, group assignments and frequently asked questions. While the evaluation of the test in the form of work or can also learn the written test. (2) The interaction between teachers and learners are good and familiar either before or during the learning classroom, which is characterized by the involvement of the student in participating in learning until the end of the teaching and learning process to make the most of the facilities provided by the teacher. Forms of interaction between teachers and learners occur in both directions, causing tradeoffs between the teachers and learners.

Keywords: learning management, learning interactions, geguritan.

\section{PENDAHULUAN}

Pendidikan yang menjawab tantangan masa depan menurut Semi (2008: 137) adalah pendidikan yang memberikan kebebasan berpikir, pertimbangan, perasaan, dan imajinasi untuk talenta serta sebanyak mungkin bertanggung jawab dalam setiap tindakannya. Dalam hubungan ini, pendidikan harus mampu menciptakan peserta didik untuk mengembangkan imajinasi kreativitas, serta mampu menjadi manusia seutuhnya, yaitu jiwa dan raga, intelegensi, kepekaan sosial, rasa estetika, dan tanggung jawab pribadi. Sekolah juga harus mampu membina peserta didik agar mempunyai kemampuan untuk berpikir kritis, kreatif, ketrampilan berkomunikasi, dan berkehidupan sosial. Dengan demikian, pengajaran sastra harus mendapat tempat yang penting dalam memberi penghargaan tinggi pada karya sastra.

Pembelajaran membaca merupakan suatu kesatuan yang tak terpisahkan dengan pembelajaran bahasa. Hal tersebut karena membaca berhubungan erat dengan bahasa, yaitu bahasa sebagai media sastra. Pembelajaran sastra dapat membantu siswa dalam usaha meningkatkan keterampilan berbahasa yang dipelajarinya. Peningkatan keterampilan yang dimaksud adalah keterampilan menulis, membaca, menyimak, dan mengemukakan pendapat kepada orang lain baik secara lisan maupun tertulis.

Mengingat penggunaan bahasa puisi yang padat, singkat, dan mengandung katakata kias, pemahaman puisi tidak dapat dipahami dengan baik tanpa pengetahuan dan pengertian yang baik terhadap karya sastra. Oleh karena itu, diperlukan cara-cara yang tepat untuk memahaminya. Salah satu cara untuk memperkenalkan sistem sastra adalah dengan metode pengajaran yang diyakini dapat mempermudah peserta didik dalam memahami karya sastra, khususnya puisi.

Pembelajaran puisi merupakan bagian dari pengajaran sastra, sedangkan pembelajaran sastra di sekolah menengah pertama dimasukkan ke dalam pembelajaran 
bahasa. Oleh karena itu sebagai konsekuensinya, perbandingan bobot pembelajaran bahasa dan sastra hendaknya seimbang dan dapat disajikan secara terpadu. Berdasarkan deskripsi tersebut, dapat dipahami jika prosentase alokasi waktu pembelajaran puisi sepertiga dari pembelajaran sastra. Dengan demikian, alokasi waktu yang tersedia untuk pembelajaran puisi sangat sempit.

Berdasarkan observasi dapat dikatakan bahwa pembelajaran sastra di SMP Negeri 3 Sukoharjo belum seperti yang diharapkan. Banyak kendala yang dihadapi oleh guru dalam proses belajar-mengajar, seperti ketersediaan buku penunjang untuk pembelajaran sastra masih minim, kurangnya pengembangan dalam strategi pembelajaran, dan jarangnya pelatihan guru. Permasalahan lain yang muncul adalah kemampuan siswa tergolong rendah. Hal tersebut mengakibatkan motivasi siswa dalam belajar menurun. Selain itu tingkat ekonomi siswa berada pada tingkat menengah kebawah.

Usaha peningkatan apresiasi siswa terhadap sastra, khususnya puisi tentunya dengan meningkatkan kesadaran bahwa sastra (puisi) memang ada manfaatnya bagi hidup dan kehidupan. Salah satu cara yang dapat dilakukan oleh guru untuk mengkreasikan pembelajaran sastra adalah dengan memilih strategi pembelajaran yang sesuai dengan situasi dan kondisi. Dalam proses belajar-mengajar strategi pengajaran mempunyai peranan penting. Pemilihan strategi pembelajaran apresiasi sastra dapat menciptakan kondisi belajar yang mendukung pencapaian tujuan pembelajaran. Strategi belajar mengajar yang dipilih dan dipergunakan dengan baik oleh guru dapat mendorong siswa untuk belajar dan aktif mengikuti kegiatan pembelajaran yang dilakukan di dalam kelas.

\section{METODE PENELITIAN}

Jenis penelitian ini adalah penelitian kualitatif, karena dalam mengkaji masalah, peneliti tidak membuktikan atau menolak hipotesis yang dibuat sebelum penelitian tetapi mengolah data dan menganalisis suatu masalah secara non numerik. Berdasarkan rangkaian teori tentang penelitian kualitatif tersebut, peneliti berkeyakinan untuk menggunakan jenis penelitian deskriptif, karena jenis penelitian ini memusatkan pada deskripsi data yang berupa kalimat-kalimat yang memiliki arti mendalam yang berasal dari informan dan perilaku yang diamati. Dalam penelitian kualitatif, data yang diambil 
adalah berupa kata-kata tertulis atau lisan serta perilaku yang diamati dari objek penelitian. Data yang dikumpulkan harus dapat menggambarkan atau melukiskan objek yang diteliti sesuai dengan keadaan yang sebenarnya. Data yang dikumpulkan harus berbentuk kalimat yang memiliki arti luas, berasal dari transkip wawancara, catatan, wawancara lapangan, catatan-catatan resmi dan sebagainya. Penelitian kualitatif merupakan suatu bentuk penelitian yang mengubah dan menganalisis suatu masalah secara non numerik.

Lokasi yang diambil oleh peneliti untuk melakukan penelitian adalah SMP Negeri 3 Sukoharjo yang terletak di Jl. Dr. Sutomo No. 1 Sukoharjo, dengan pertimbangan di SMP Negeri 3 Sukoharjo, terdapat permasalahan terkait dengan pembelajaran apresiasi puisi Jawa, dan di SMP Negeri 3 peneliti mudah mendapatkan data yang diperlukan dalam penelitian. Waktu Penelitian dilakukan mulai bulan September 2011 sampai dengan bulan Desember 2011.

\section{Sumber Data}

\subsection{Nara sumber}

Dalam penelitian kualitatif posisi sumber data manusia (nara sumber) sangat penting peranannya sebagai individu yang memiliki informasi. Peneliti dan nara sumber disini memiliki posisi yang sama dan nara sumber bukan memberikan sekedar tanggapan pada yang diminta peneliti, tetapi ia lebih bisa memilih arah dan selera dalam menyajikan informasi yang ia miliki. Informan dalam penelitian adalah guru SMP Negeri 3 Sukoharjo.

\subsection{Peristiwa atau aktivitas}

Data atau informasi juga dapat dikumpulkan dari peristiwa, aktivitas, atau perilaku sebagai sumber data yang berkaitan dengan sasaran penelitiannya. Dari pengamatan pada peristiwa atau aktivitas, peneliti bisa mengetahui proses bagaimana sesuatu terjadi secara lebih pasti karena menyaksikan sendiri secara langsung. Peristiwa sebagai sumber data memang sangat beragam, dari berbagai peristiwa, baik yang terjadi secara sengaja ataupun tidak, aktivitas rutin yang berulang atau yang hanya satu kali terjadi, aktivitas yang formal maupun yang tidak formal, dan juga yang tertutup ataupun yang terbuka untuk bisa diamati oleh siapa saja. 


\subsection{Dokumen dan Arsip}

Dokumen dan arsip bukan hanya menjadi sumber data yang penting bagi penelitian kesejarahan, tetapi juga dalam penelitian kualitatif pada umumnya. Dalam mengkaji dokumen maupun arsip, peneliti perlu menguji keaslian dokumen tersebut, bisa lewat kesaksian seseorang yang tahu, atau dengan mengkaji beragam aspek formalnya. Perlu juga disadari bahwa dokumen atau arsip yang asli pun belum tentu isinya benar.

Berbagai permasalahan memang memerlukan pemahaman lewat kajian terhadap perilaku atau sikap dari para pelaku dalam lewat kajian terhadap perilaku atau sikap dari para pelaku dalam aktivitas yang dilakukan atau yang terjadi sebenarnya. Bukan hanya lewat kajian terhadap perilaku atau sikap dari para pelaku dalam aktivitas yang dilakukan atau yang terjadi sebenarnya. Bukan hanya lewat informan yang diberikan oleh seseorang atau dari catatan-catatan yang ada mengenai aktivitas tertentu. Namun perlu dipahami bahwa tidak semua peristiwa bisa diamati secara langsung, kecuali ia merupakan aktivitas yang masih berlangsung pada saat penelitian dilakukan. Banyak peristiwa yang hanya terjadi satu kali, atau hanya berjalan dalam jangka waktu tertentu dan tidak terulang kembali. Dalam hal semacam ini, kajian lewat peristiwanya secara langsung tidak bisa dilakukan, kecuali lewat cerita narasumber, atau dokumen rekaman dan gambar bila ada.

Aktivitas atau peristiwa yang digunakan dalam penelitian ini adalah aktivitas atau peristiva pengelolaan pembelajaran apresiasi puisi Jawa yang sedang berlangsung di SMP Negeri 3 Sukoharjo.

\section{Pengumpulan Data}

Dalam penelitian kualitatif wawancara dilakukan secara bebas terkontrol artinya wawancara dilakukan secara bebas sehingga diperoleh data yang luas dan mendalam, tetapi masih memperhatikan unsur terpimpin pada persoalan-persoalan yang diteliti dalam hal inilah pedoman wawancara digunakan.

Berdasarkan data yang diperoleh berupa pembelajaran apresiasi puisi jawa, maka pengembangan validitas data digunakan trianggulasi sumber/data. Hal ini dipilih karena beragam sumber data tersedia dalam pembelajaran ini, yaitu antara lain karangan, guru, siswa, dan dokumen. 
Peneliti meminta kembali penjelasan, atau informasi baru dari informan yang sama dan pertanyaan yang sama tetapi dengan waktu dan situasi yang berbeda. Pengecekan dilakukan untuk mengecek kebenaran data hasil wawancara tentang pembelajaran apresiasi puisi Jawa di SMP Negeri 3 Sukoharjo.

Trianggulasi sumber/data yang memanfaatkan jenis sumber data yng berbedabeda untuk menggali data sejenis, tekanannya pada perbedaan sumber data, bukan pada teknik pengumpulan data atau yang lain. Peneliti bisa memperoleh dari narasumber yang berbeda-beda posisinya dengan teknik wawancara mendalam, sehingga informasi dari narasumber yang satu bisa dibandingkan dengan informasi dari narasumber lainnya.

\subsection{Teknik Pengumpulan Data}

\subsubsection{Wawancara Mendalam}

Dalam penelitian kualitatif wawancara dilakukan secara bebas terkontrol artinya wawancara dilakukan secara bebas sehingga diperoleh data yang luas dan mendalam, tetapi masih memperhatikan unsur terpimpin pada persoalan-persoalan yang diteliti dalam hal inilah pedoman wawancara digunakan. Wawancara digunakan untuk mengumpulkan data-data yang lebih lengkap tentang temuan data yang diperoleh dari proses pembelajaran berlangsung. Untuk itu dilakukan rujuk silang data yang berhubungan antara data proses pembelajaran dengan pelaku pembelajaran, yaitu guru dan siswa.

\subsubsection{Dokumentasi}

Semua data yang berupa dokumentasi dalam penelitian ini merupakan data sekunder, sedangkan data primer dalam penelitian ini adalah semua data yang diperoleh langsung dari informan. Dengan demikian, maka penelitian tidak hanya dilakukan dengan mengumpulkan data melalui teknik pengumpulan dan wawancara, melainkan juga dengan teknik dokumentasi, walaupun kedua teknik itu dianggap sebagai teknik utama yang merupakan teknik yang paling dominan dipergunakan.

\subsection{Pengembangan Validitas Data}

Berdasarkan data yang diperoleh berupa pembelajaran apresiasi puisi jawa, maka pengembangan validitas data digunakan trianggulasi sumber/data. Hal ini dipilih karena beragam sumber data tersedia dalam pembelajaran ini, yaitu antara lain karangan, guru, siswa, dan dokumen. 
Trianggulasi data merupakan teknik pemeriksaan keabsahan data yang memanfaatkan sesuatu yang lain di luar data itu untuk keperluan pengecekan atau sebagai pembanding terhadap data yang diperoleh melalui wawancara, untuk mencari atau memperoleh standar kepercayaan data yang diperoleh dengan jalan melakukan pengecekan data, cek ulang dan cek silang pada dua atau lebih informasi. Setelah mengadakan wawancara dan observasi, peneliti mengadakan penelitian kembali, mencocokkan data yang diberikan oleh informan satu dengan informan lainnya. Peneliti meminta kembali penjelasan, atau informasi baru dari informan yang sama dan pertanyaan yang sama tetapi dengan waktu dan situasi yang berbeda. Pengecekan dilakukan untuk mengecek kebenaran data hasil wawancara tentang pembelajaran apresiasi puisi Jawa di SMP Negeri 3 Sukoharjo.

Trianggulasi data yang digunakan dalam penelitian ini adalah trianggulasi sumber data yaitu teknik pemeriksaan keabsahan data dimana peneliti dalam mengumpulkan data wajib menggunakan beragam sumber data yang berbeda-beda dan yang tersedia. Artinya, data yang sama atau sejenis akan lebih mantap kebenarannya bila digali dari beberapa sumber data yang berbeda. Dengan demikian apa yang diperoleh dari sumber data satu, bisa lebih teruji kebenarannya bilamana dibandingkan dengan data sejenis yang diperoleh dari sumber data yang lain yang berbeda, baik kelompok sumber sejenis atau sumber data yang berbeda jenisnya.

Trianggulasi sumber/data yang memanfaatkan jenis sumber data yng berbedabeda untuk menggali data sejenis, tekanannya pada perbedaan sumber data, bukan pada teknik pengumpulan data atau yang lain. Peneliti bisa memperoleh dari narasumber yang berbeda-beda posisinya dengan teknik wawancara mendalam, sehingga informasi dari narasumber yang satu bisa dibandingkan dengan informasi dari narasumber lainnya.

\subsection{Analisis Data}

Proses analisis dalam penelitian ini dilakukan secara bersamaan dengan proses pelaksanaan pengumpulan data. Data yang telah diperoleh diberi kode sesuai dengan tahapan perolehan atau pengkodean secara kronologis. Selain itu, data yang diperoleh berdasarkan wawancara dan observasi, data diberi kode atau dilakukan pengkodean berdasarkan perolehan data dari sumber data yaitu dengan kode CL untuk catatan lapangan dan CLO untuk catatan lapangan observasi. 
Data-data yang sudah diberi kode dan isinya hampir sama dimasukkan ke dalam beberapa kelompok dan dimasukkan ke amplop dan diberi judul kecil. Selain itu datadata juga dimasukkan ke dalam data base di komputer. Data-data ini sebagai data mantap yang akan dilaporkan sebagai hasil penelitian. Setelah pengumpulan data seperti tersebut di atas selesai, mulailah dengan proses analisis secara kualitatif.

\subsubsection{Reduksi Data}

Reduksi data merupakan proses seleksi, pemfokusan, penyederhanaan, dan abstraksi dari semua jenis informasi yang tertulis lengkap dalam catatan lapangan. Reduksi data berlangsung terus-menerus sepanjang penelitian. Artinya, pada waktu pengumpulan data berlangsung, reduksi data dilakukan dengan membuat ringkasan isi dari catatan data yang diperoleh di lapangan.

Dalam penelitian ini, data-data yang diperoleh dari proses pembelajaran, datadata dari dokumen dan arsip secara otomatis peneliti melakukan refleksi dan analisis data sekaligus merefleksi data-data tersebut. Hasil dari reduksi data merupakan temuan data yang layak disajikan untuk pembahasan selanjutnya dengan cara merujuksilang antar unit analisis.

\subsubsection{Sajian Data}

Sajian data disusun berdasarkan pokok-pokok yang terdapat dalam reduksi data yang disajikan dengan menggunakan kalimat dan bahasa peneliti dan merupakan rangkaian kalimat yang disusun secara logis dan sistematis, sehingga mudah dibaca dan dipahami.

Data yang tersaji merupakan hasil penelitian yang dideskrisikan secara runtut sesuai dengan rangkaian unit analisis dalam proses pembelajaran yang telah diamati oleh peneliti. Data-data yang tersaji disusun berdasarkan rangkaian pembelajaran, yaitu dari persiapan pembelajaran yang berupa dokumen seperti silabus, materi ajar, dan (RPP). Kemudian mendeskripsikan proses pembelajaran, dan berikutnya mendeskripsikan tata cara guru dalam evaluasi pembelajaran.

\subsubsection{Penarikan Simpulan dan Verifikasi}

Segala sesuatu yang telah ditemukan berdasarkan data, merupakan kepekaan peneliti dalam menangkap keterkaitan logis antar data. Kepekaan temuan data ini merupakan simpulan peneliti yang harus dijelaskan secara berkelanjutan sehingga dapat 
dijelaskan secara eksplisit dengan landasan yang kuat. Simpulan harus diverifikasi agar mantap dan benar-benar dapat dipertanggungjawabkan.

Berdasarkan uraian di atas, maka teknik analisis yang digunakan dalam penelitian ini adalah model analisis interaktif. Analisis interaktif dimulai pada waktu pengumpulan data, peneliti selalu membuat reduksi data. Artinya, data yang berupa catatan lapangan yang terdiri dari bagian deskripsi dan refleksinya adalah data yang telah digali dan dicatat. Kemudian dari dua bagian data tersebut disusun rumusan pengertiannya secara singkat, berupa pokok-pokok temuan yang penting dalam arti inti pemahaman segala peristiwa yang dikaji yaitu reduksi data.

\section{PEMBAHASAN}

Pengelolaan pembelajaran direncanakan sesuai dengan RPP Bahasa Jawa yang telah dibuat oleh guru sebelum pelaksanaan pembelajaran, dengan demikian perencanaan pembelajaran apresiasi geguritan merupakan bagian dari rencana pelaksanaan pembelajaran bahasa Jawa secara keseluruhan. Dalam rencna pelaksanaan pembelajaran apresiasi geguritan, guru merencfanakan materi ajar, metode pembelajaran, media pembelajaran yang disesuaikan dengan standar kompetensi dan kompetensi dasar yang telah ditetapkan.

Geguritan merupakan karya sastra, dalam melalui geguritan guru dapat mengetahui kemampuan siswa dalam membaca, dan mendengarkan puisi Jawa, dimana aspek membaca dan mendengarkan merupakan aspek dalam penilaian kemampuan siswa dalam berbahasa. Dalam geguritan memiliki ciri khas tersendiri, sehingga dalam pengelolaan pembelajaran bahasa Jawa, khususnya apresiasi geguritan, guru harus benar-benar mempersiapkan dengan baik. Karena geguritan merupakan karya sastra yang mempunyai gaya bahasa atau ciri khas tersendiri. Segala unsur seni mengental di dalamnya. Geguritan sebagai salah satu karya sastra tulis yang mempunyai nilai tersendiri bagi penulis dan pembacanya dan untuk memahaminya diperlukan pengetahuan tentang majas dan fungsinya.

Pelaksanaan pembelajaran yang dilakukan melalui 3 (tiga) kegiatan yaitu kegiatan pendahuluan, kegiatan inti dan kegiatan penutup menunjukkan bahwa dalam pelaksanaan pembelajaran Guru telah memahami pentingnya tahap-tahap pembelajaran, walaupun pembelajaran apresiasi geguritan merupakan mata pelajaran muatan lokal, 
guru tetap tidak mengesampingkan langkah-langkah pembelajaran. Penekanan guru pada aspek membaca dan mendengarkan dilakukan oleh guru melalui kegiatan unjuk kerja, ceramah, demonstrasi, penugasan kelompok dan tanya jawab, merupakan bentuk upaya guru, agar pembelajaran apresiasi geguritan yang disampaikan kepada siswa dapat mencapai tujuan yang telah ditetapkan.

Pengelolaan pembelajaran apresiasi geguritan, guru menerapkan metode agar siswa dapat mengungkap makna geguritan meliputi meliputi: (a) diksi (diction); (b) imaji (imagery); (c) kata nyata (the concrete word); (d) majas (figurative language); (e) ritme dan rima (rhytem and rime). Selanjutnya dalam memahami sebuah puisi diperdalam dengan menganalisis struktur fisik dan struktur batin, hal ini sesuai dengan teori yang dikemukakan oleh Morris (2007: 617-622).

\section{Pengelolaan Pembelajaran Apresiasi Geguritan di SMP Negeri 3 Sukoharjo}

Pengelolaan pembelajaran direncanakan sesuai dengan RPP Bahasa Jawa yang telah dibuat oleh guru sebelum pelaksanaan pembelajaran, dengan demikian perencanaan pembelajaran apresiasi geguritan merupakan bagian dari rencana pelaksanaan pembelajaran bahasa Jawa secara keseluruhan. Dalam rencna pelaksanaan pembelajaran apresiasi geguritan, guru merencfanakan materi ajar, metode pembelajaran, media pembelajaran yang disesuaikan dengan standar kompetensi dan kompetensi dasar yang telah ditetapkan.

Adanya kegaitan guru menyusun perencanaan pembelajaran apresiasi geguritan yang telah disesuaikan dengan standar kompetensi dan kompetensi dasar menunjukkan bahwa guru telah memahami isi kurikulum dan silabus bahasa Jawa yang telah ditetapkan, sehingga RPP pembelajaran geguritan merupakan pengembangan dari kurikulum dan silabus yang telah ada.

Pengelolaan pembelajaran apresiasi geguritan yang telah dilakukan oleh guru dalam bentuk kegiatan perencanaan, pelaksanaan, dan evaluasi pembelajaran, merupakan salah satu bagian dari pembelajaran bahasa Jawa. Pembelajaran Bahasa Jawa berdasarkan Kurikulum 2010 lebih menekankan kepada pendekatan komunikatif yaitu pembelajaran yang mempermudah para siswa agar lebih akrab dalam pergaulan dengan menggunakan Bahasa Jawa dan melatih siswa untuk lebih senang berbicara menggunakan Bahasa Jawa yang benar dan tetap sesuai dengan situasinya, untuk itu 
dalam pembelajaran guru merencanakan dalam bentuk rencana pelaksanaan pembelajaran (RPP) secara detail.

Penyusunan rencana pelaksanaan pembelajaran yang disesuaikan dengan kalender pendidikan merupakan salah satu upaya guru agar pembelajaran bahasa Jawa, dapat berjala secara berkesinambungan selaras dengan kompetensi dasar yang satu dengan kompetensi dasar lainnya, dengan tetap memperhatikan 4 (empat) aspek dalam pembelajaran bahasa Jawa, yaitu: Mendengarkan, Berbicara, Membaca, Menulis. Keempat aspek tersebut tidak dapat terpisah antara satu aspek dengan aspek lainnya, sehingga secara spesifik guru menyusun rencana pembelajaran menurut jadwal dan alokasi waktu yang telah ditetapkan.

Geguritan merupakan karya sastra, dalam melalui geguritan guru dapat mengetahui kemampuan siswa dalam membaca, dan mendengarkan puisi Jawa, dimana aspek membaca dan mendengarkan merupakan aspek dalam penilaian kemampuan siswa dalam berbahasa. Dalam geguritan memiliki ciri khas tersendiri, sehingga dalam pengelolaan pembelajaran bahasa Jawa, khususnya apresiasi geguritan, guru harus benar-benar mempersiapkan dengan baik. Karena geguritan merupakan karya sastra yang mempunyai gaya bahasa atau ciri khas tersendiri. Segala unsur seni mengental di dalamnya. Geguritan sebagai salah satu karya sastra tulis yang mempunyai nilai tersendiri bagi penulis dan pembacanya dan untuk memahaminya diperlukan pengetahuan tentang majas dan fungsinya.

Perencanaan apresiasi geguritan telah disusun oleh guru bahasa Jawa pada awal semester, hal ini menunjukkan bahwa guru berupaya agar pelaksanaan pembelajaran nantinya dapat dilakukan sesuai dengan jadwal pelajaran dan kalender pendidikan yang telah ditetapkan, dengan tetap berpedoman pada arah pembelajaran yang telah ditetapkan sebelumnya. Selain itu guru telah memiliki kesadaran pentingnya perencanaan pembelajaran dalam mencapai tujuan pembelajaran.

Adanya kegiatan guru dalam menyusun perencanaan pembelajaran, menunjukkan bahwa guru telah mempersiapkan pembelajaran apresiasi geguritan dengan sungguh-sungguh, dan menujukkan bahwa guru telah menyadari bahwa RPP merupakan rencana yang menggambarkan prosedur dan manajemen pembelajaran untuk mencapai satu atau lebih kompetensi dasar yang ditetapkan dalam Standar Isi dan dijabarkan dalam silabus". RPP merupakan komponen penting dari kurikulum yang 
dipergunakan pada program percepatan belajar yang mengacu pada KTSP. RPP pengembangannya harus dilakukan secara profesional.

Evaluasi pembelajaran apresiasi geguritan dilakukan oleh guru sebagaimana evaluasi pada umumnya, yaitu berupa serangkaian proses pembelajaran yang berfungsi sebagai alat pengukur keberhasilan suatu pembelajaran. mengkategorikan evaluasi dalam pembelajaran sastra (puisi) ada empat tingkatan dasar untuk memahami puisi. Indikator pertanyaan tingkatan ini telah dipergunakan kata-kata seperti (1) apa, siapa, dimana dan kapan; (2) konsep, yakni pertanyaan tentang persepsi sebuah pusi; (3) perspektif, yakni pertanyaan yang menyangkut pandangan tentang sebuah karya, dan lain-lain, dan (4) apresiasi, yakni pertanyaan yang menyangkut aspek kesastraan dan kebahasaan.

\section{Interaksi Pembelajaran Apresiasi Geguritan di SMP Negeri 3 Sukoharjo}

Interaksi antara guru dan peserta didik terjalin dengan baik dan akrab baik itu sebelum pembelajaran maupun pada saat pembelajaran di kelas. Dimana dalam pembelajaran apresiasi geguritan siswa telah menunjukkan sikap yang aktif dalam pembelajaran. Interaksi yang terjadi antara Guru dengan peserta didik merupakan interaksi dua arah, di mana proses pembelajaran tidak hanya terfokus pada Guru saja tetapi juga mengadopsi ide-ide dari siswa. Interaksi antara guru dan siswa terjadi di dalam kelas maupun di luar kelas. Hal ini menunjukkan bahwa dalam pembelajaran apresiasi geguritan guru dan siswa saling bergantung dan tidak bersifat parsial atau berjalan sendiri-sendiri. Guru tidak akan dapat melaksanakan tugas pembelajaran tanpa ada siswa, demikian pula dengan siswa, tidak akan dapat melakukan pembelajaran dengan baik tanpa adanya guru.

Saling ketergantungan merupakan ciri dari pembelajaran dimana pembelajaran merupakan suatu proses yang sistimatis yang terdiri atas banyak komponen. Masingmasing komponen pembelajaran tidak bersifat parsial (terpisah) atau berjalan sendirisendiri, tetapi harus berjalan secara teratur, saling bergantung, komplementer, dan berkesinambungan, untuk itu diperlukan pengelolaan pembelajaran yang baik (Rohani, 2008:1).

Dalam proses belajar mengajar hubungan yang harmonis antara guru dan siswa sangat diperlukan, demikian pula dengan pembelajaran apresiasi geguritan. Keberhasilan pembelajaran apresiasi geguritan tergantung pada kedua belah pihak yaitu 
guru sebagai pendidik dan siswa sebagai anak didik. Interaksi yang efektif antara guru dan siswa akan mempermudah siswa menerima dan mempelajari pelajaran tersebut. Bagaimanapun sulitnya materi pelajaran, siswa akan mempelajarinya dengan baik. Siswa akan merasa bahwa belajar bukanlah suatu beban, apabila hubungan dengan guru berlangsung dengan baik.

Interaksi proses belajar mengajar pada prinsipnya bergantung kepada pendidik dan peserta didik. Interaksi mengisyaratkan adanya aktivitas peserta didik yang belajar maupun pendidik yang mengajar. Interaksi belajar mengajar dapat dilihat pada saat proses belajar mengajar berlangsung di sekolah. Di sekolah, interaksi belajar mengajar terjadi antara guru dan siswa, maupun antara siswa itu sendiri. Interaksi guru dan siswa merupakan faktor yang sangat penting dalam menunjang keberhasilan pembelajaran. Karena bantuan guru kepada siswa di dalam dan di luar pelajaran dapat berpengaruh, terutama dorongan yang bersifat psikis untuk penyelesaian tugas-tugas dan penyelesaian pembelajaran. Bagi siswa, guru adalah figur yang memberi semangat belajar, minimal terhadap mata pelajaran yang bersangkutan.

Terjadinya interaksi guru dan siswa tersebut memungkinkan pembelajaran dapat berjalan dengan baik, tujuan pembelajaran dapat tercapai dengan efektif dan efisien, siswa lebih tertarik dengan pembelajaran, sehingga siswa meiliki kesediaan untuk membaca, mendengarkan dan menyimak geguritan.

Berdasarkan uraian di atas, dapat dikemukakan bahwa pengelolaan pembelajaran apresiasi geguritan, dilaksanakan berdasarkan perencanaan yang telah tersusun dalam kurikulum sekolah yang telah direncanakan sebelumnya. Pengembangan kurikulum dalam bentuk perencanaan pembelajaran dilakukan oleh guru bahasa Jawa untuk mencapai perubahan sikap siswa. Dalam mengelola pembelajaran apresiasi geguritan, guru mewajibkan kepada siswa untuk mendramatisasi sesuai dengan kemampuan siswa, intonasi dalam menyampaikan geguritan dan gaya bahasa, pengungkapan perasaan, diperlukan dalam mengapresiasikan puisi, sehingga apresiasi puisi dapat memberikan motivasi kepada siswa untuk belajar lebih baik. Siswa dengan latar belakang sosial, ekonomi, dan rasa yang ada di kawasan sekolah menengah di Ohio semuanya meningkat minatnya terhadap pembelajaran sosial dengan bahan ajar puisi. Penelitian ini menyimpulkan bahwa puisi sebagai bahan ajar merupakan hal yang menyenangkan 
bagi murid. Dengan demikian, pembelajaran menulis puisi juga dapat menjadi pembelajaran yang dapat menarik minat murid.

\section{SIMPULAN DAN SARAN}

Pengelolaan pembelajaran apresiasi geguritan di SMP Negeri 3 Sukoharjo dilakukan dalam tiga tahap, yaitu tahap perencanaan, pelaksanaan, dan evaluasi pembelajaran. Perencanaan pembelajaran apresiasi Geguritan disusun oleh guru bahasa Jawa berdasarkan rencana atau RPP yang telah dibuat menurut jadwal semester atau alokasi waktu yang ada. Perencanaan pembelajaran dikembangkan oleh guru Bahasa dengan mengacu kurikulum dan silabus yang telah ada.

Pelaksanaan pembelajaran dilakukan dalam tiga tahap pembelajaran yaitu kegiatan pendahuluan, kegiatan inti dan kegiatan penutup. Kegiatan inti guru melakukan pembelajaran dengan memanfaatkan media pembelajaran dan melakukakan kegiatan elaborasi eksplorasi, konfirmasi, dengan metode bervariasi yaitu dengan unjuk kerja, ceramah, demonstrasi, penugasan kelompok dan tanya jawab. Sedangkan evaluasi berbentuk uji petik kerja atau bisa juga test tertulis. Guru menggunakan media pembelajaran multimedia. Dalam membawakan geguritan dilakukan oleh 2 (dua) orang siswa secara bergantian dan bersautan.

Seyogyanya kepala sekolah memberikan perhatian terhadap pelaksanaan pembelajaran apresaiasis geguritan, dengan melakukan supervisi secara intensif agar pembelajaran apresiasi geguritan dapat dilaksanakan sebaik-baiknya.

Seyogyanya guru dapat mengembangkan pembelajaran apresiasi geguritan dengan mengoleksi berbagai geguritan baik berupa buku, maupun sumber lainnya. Sebaiknya secara aktif mencoba untuk menulis geguritan, sebagai sarana mengembangkan kreativitas dan kemampuan dalam belajar sastra Jawa.

\section{DAFTAR PUSTAKA}

Ahmadi, Muksin. 2008. Strategi Mengajar Keterampilan Berbahasa dan Apresiasi Sastra. Malang: Yayasan Asah Asuh Asih.

Andayani, 2009, Pembelajaran Apresiasi Puisi Rekreatif di SMK, Program Pendidikan Bahasa dan Sastra Indonesia, FKIP Universitas Sebelas Maret, Surakarta

Arikunto, Suharsimi. 2006. Prosedur Penelitian Suatu Pendekatan Praktek. Jakarta: PT. Rineka Cipta. 
Billow. 2006. Technique of Language Teaching. London: Longman.

Blair, Walter and W.K. Chandler. 2006. Approaches to Poetry. New York: D. Appeton to Literature.

Depdikbud, 1994, Kurikulum Sekolah Lanjutan Tingkat Atas, Jakarta: Depdikbud.

Djamarah, Syaiful Bahri. 2006. Strategi Belajar Mengajar. Jakarta: PT.Rineka Cipta.

Effendi. 2007. Bimbingan Apresiasi Puisi. Ende Flores: Nusa Indah.

Elting dan Firkins. 2006. Dramatizing Poetry in the Second Language Classroom. English Teaching: Practice and Critique, December, 2006, Vol. 5, No. 3, pp: 127-136, http://www.proquest.umi.com diakses pada tanggal 28 Oktober 2009.

Gani, Rizanur. 2007. Guru Sastra yang Konstruktif dalam Sastra Masuk Sekolah. Editor Riris K. Toha Sarumpaet, Magelang: Indonesia Tera.

Ghazali, Syukur A. 2005. "Metode pengajaran Sastra dengan Strategi Belajar Kooperatif (Cooperative Learning): Mengubah Aktifitas Guru-Siswa dikelas" dalam Sastra Masuk Sekolah. Editor : Riris K. Toha-Sarumpaet. Magelang: Indonesia Tera.

Hamalik, Oemar. 2006. Proses Belajar Mengajar. Jakarta: PT. Bumi Aksara.

Hamalik, Oemar, 2007. Manajemen Pengembangan Kurikulum, Bandung: PT. Remaja Rosda Karya.

Jabrohim. 2005. Pengajaran Sastra. Yogyakarta: Penerbit Pelajar.

Kazemek. 2006. Everybody Likes Poems Celebrating Poetry and Literacy in The Classroom, School, and Community, Thinking Classroom, Vol.7.Iss.3.pp.38-45

Kennedy, XJ. 2007. An Introduction to Poetry. Boston: Little Brown and Company.

Mantja, W. 2005. Etnografi Disain Penelitian Kualitatif dan Manajemen Pendidikan. Malang: Penerbit Wineka Media.

Moleong, Lexy J. 2007. Metodologi Pendidikan Kualitatif. Bandung: PT Remaja Rosdakarya.

Moody H. L. B. 2006. The Teaching of Literature. London: Longman.

Morris, Alton C. et. al. 2007. College English, the First Year. New York : Harcourt, Brace \& World. Inc. 
Mulyasa, E. 2006. Kurikulum Tingkat Satuan Pendidikan. Bandung: PT. Remaja Rosdakarya.

Nasution. 2007. Asas-Asas Kurikulum. Jakarta : Bumi Aksara.

Nurhadi. 2004. Dasar-dasar Pendidikan. Jakarta: Bumi Aksara.

Pidarta, Made. 2004. Manajemen Berbasis Sekolah. Bandung: PT. Remaja Rosda Karya.

Poerwadarminta. (2006). Kamus Besar Bahasa Indonesia. Jakarta : Balai Pustaka

Rahmanto, B. 2006. Metode Pengajaran Sastra. Yogyakarta: Kanisius.

Richards, R. A. 2005. Practical Critism. London: Raudledge and Keagen Paul.

Rohani, Ahmad. 2004. Pengelolaan Pengajaran. Jakarta: PT. Rineka Cipta.

Russell, Vivienne. 2007. Plans for Slimmer, more flexible curriculum welcomed. Public Finance. Academic Research Library. pg. 11.

Sayuti, Suminto A. 2007. "Pengantar Pengajaran Puisi" dalam Pengajaran Sastra. Editor : Jabrohim. Yogyakarta : Pustaka pelajar.

Sekeres, Diane Carver \& Madeleine Gregg. 2007. Poetry in Third Grade: Getting Started. The Reading Teacher. Vol 60. Iss.5. pp.466-476

Semi, M. Atar. 2008. "Buku Pendukung Pengajaran Sastra" dalam Sastra Masuk Sekolah. Editor : Riris K. Toha-Sarumpaet. Magelang: Indonesia Tera.

Situmorang, B. P. 2006. Puisi dan Metodologi Pengajarannya. Ende Flores, Nusa Indah.

Sudjana, Nana. 2007. Evaluasi Pembelajaran. Bandung: Remaja Rosdakarya.

Sukirman, Dadang. 2008. Pembelajaran Mikro. Bandung: UPI Press.

Sumantri, Mulyani. 2006. Kurikulum dan Pengajaran. Jakarta: Proyek LPTK.

Susilo, Joko Muhammad. 2007. Kurikulum Tingkat Satuan Pendidikan. Yogyakarta: Pustaka Pelajar Offset.

Sutopo, H.B. 2005. Metodologi Penelitian Kualitatif. Surakarta: Sebelas Maret University Press.

Tarigan, Henry Guntur. 2008. Prinsip-Prinsip Dasar Sastra. Bandung: Angkasa. 
Kawruh: Journal of Language Education, Literature, and Local Culture

Volume 1, Nomor 1, 2019 P-ISSN: 2657-134X

E-ISSN: 2657-1625

Waluyo, Herman J. 2008. Bimbingan Telaah Puisi. Surakarta: FKIP Universitas Sebelas Maret.

Warsito, 2008, Kamus Jawa Kuna Indonesia, Ende Flores: Nusa Indah.

Webb, David. 2007. Teaching Modern Languages. London: David \& Charles.

Yulaelawati, Ella. 2004. Kurikulum dan Pembelajaran Filosofi Teori dan Aplikasi. Bandung: Penerbit Paka Raya.

Zamroni. 2006. Paradigma pendidikan Masa Depan. Yogyakarta: BIDRAF Publishing. 